\title{
HOTAIR: a cancer-related long non-coding RNA
}

\author{
Minireview
}

B. CAI ${ }^{1}$, X. Q. SONG ${ }^{1}$, J. P. CAI ${ }^{2, *}$, S. ZHANG ${ }^{1, *}$

${ }^{1}$ Department of Colorectal Surgery, The First Affiliated Hospital, Guangxi Medical University; ${ }^{2}$ Department of Orthopedics, Wuxi City Hospital of Chinese Medicine

*Correspondence: zs0771@hotmail.com,cb1988cn@126.com

Received December 6, 2013 / Accepted March 5, 2014

\begin{abstract}
Long non-coding RNA was dismissed as merely transcriptional "noise" in the past decades. Numerous researches have shown that lncRNAs regulated gene expression at the epigenetic level. Moreover, lncRNAs played important roles in proliferation, apoptosis and invasiveness of tumor cells, and participated in metastatic capacity of cancers. Recent studies revealed HOX transcript antisense RNA, a lncRNA with regulatory functions of transcription, could bind PRC2 and LSD1/CoREST/REST complexes and direct to the specific gene sites, resulted in H3K27 methylation and H3K4 demethylation and ultimately gene silencing. Aberrant HOTAIR expression was associated with various sites of cancers such as breast, hepatocellular, gastric, colorectal, pancreatic et al; and affected survival and prognosis of cancer patients. In this review, we introduce an overall view of HOTAIR by describing the known molecular mechanisms and potential functions of HOTAIR and summarizing the latest progresses on the research of HOTAIR in various human cancers.
\end{abstract}

Key words: HOTAIR, LncRNA, HOX genes, cancer

Long non-coding RNAs (LncRNAs) are commonly defined as RNA moleculars larger than 200 nucleotides. LncRNA was first found among transcribed DNA product of the mouse by Okazaki [1]. Many identified lncRNAs were transcribed by RNA polymerase II (RNA pol II) and spliced [2,3]. One view existed in the past few decades that lncRNAs were as diverse as their better known counterpart messenger RNAs (mRNAs), having no protein-coding capacity, were described as transcriptional "noise" $[4,5,6]$. However, a number of studies have shown that some lncRNAs were involved in embryogenesis and differentiation $[7,8]$. These $\operatorname{lncRNAs}$ are expressed in specific cell types $[9,10,11]$ and located in specific subcellular compartments $[12,13,14]$. Moreover, recent studies have indicated that IncRNAs participated in a wide range of biological pathways and cellular processes. They could regulate gene expression and function, including dosage compensation $[15,16]$, genome rearrangement [17], chromatin modifications $[7,18,19]$, gene imprinting [20,21, 22], alternative splicing [23], nuclear-cytoplasmic trafficking $[24,25,26]$, cell cycle control $[27,28,29]$ and inactivation of major tumor suppressor genes [30,31]. Wang et al [32] summarized the functions of lncRNAs as signals [33], decoys [34, 35], guides [15] and scaffolds $[18,36]$.

HOX transcript antisense RNA (HOTAIR) is a lncRNA which has regulatory functions of transcription and are transcribed from the antisense strand of homeobox $C$ gene locus in chromosome 12. HOTAIR recruits Polycomb Repressive Complex 2 (PRC2) and histone demethylase complex [LSD1 (lysine specific demethylase 1)/CoREST (Co-repressor of RE1-silencing transcription factor)/REST]; then leads to histone $\mathrm{H} 3$ tri-methylated at lysine 27 (H3K27me3) and histone $\mathrm{H} 3$ dimethyl Lys4 (H3K4me2); consequently results in gene silencing. In addition to its scaffold function to assemble transcription regulators, and a latest study reported that HOTAIR could also serve as a platform to control protein levels via the ubiquitin-proteasome pathway. HOTAIR facilitated the ubiquitination of Ataxin-1 by Dzip3 and Snurportin-1 by Mex $3 \mathrm{~b}$, and then accelerated their degradation. Moreover, HOTAIR levels were highly upregulated in senescent cells. It 


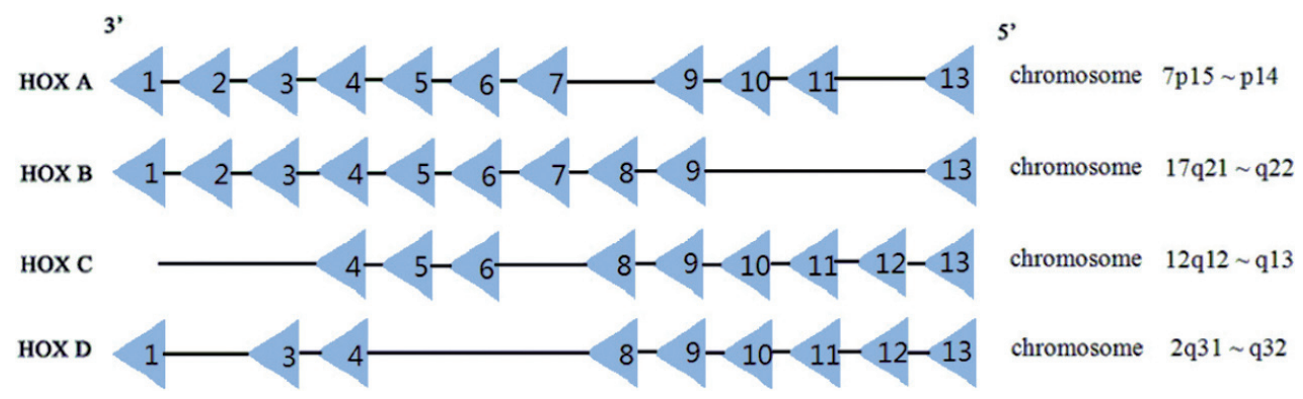

Figure 1. Structures of HOX genes.

could cause rapid decay of targets Ataxin-1 and Snurportin-1, and prevented premature senescence [37].

As more and more attention has been focused on HOTAIR, it has been revealed that HOTAIR had significant relationships with a variety of cancers such as breast [38], hepatocellular [39], colorectal [40], pancreatic [41], etc. The expression level of HOTAIR was associated with the viability, proliferation and invasion of tumor cells, and effected the survival and prognosis of cancer patients. Although the precise mechanisms of HOTAIR in cancer progression are not entirely clear, it has become increasingly obvious that HOTAIR potentially associated with cancer development and metastasis. With HOTAIR becomes a hot research topic recently, our review introduces previous studies on HOTAIR and HOTAIR-related cancers, describes the known functions and possible underlying mo-

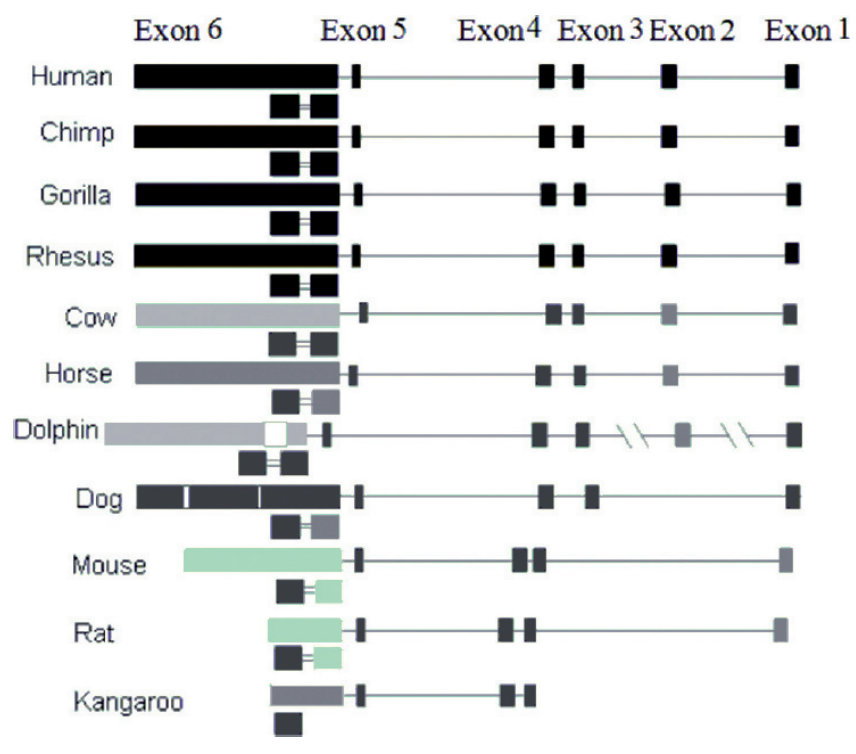

Figure 2. Structures of HOTAIR exons.

Exon1, exon3, exon4, exon 5 and domain B of exon 6 are better conserved than exon2, exon 6 and domain A of exon6 (indicated by the darkness of the boxes). The two boxes under each exon6 are domain $A$ (right side) and domain B (left side), linked by a double line indicating a gap of $130 \mathrm{bp}$ (Figure modified from Ref 54). lecular mechanisms of HOTAIR and points out the current questions and prospects.

\section{Homeobox genes}

Homeobox genes (HOX genes) were discovered in Drosophila by Lewis in 1978 [42]. HOX gene encodes for a 60 amino acid DNA-binding domain called the homeodomain, which is a 180-bp DNA sequence and highly conserved in evolution. There are $39 \mathrm{HOX}$ genes in mammals, which are divided into A, B, C, D four clusters. Each cluster contains 9 to 11 genes Figure 1. HOX genes are demarcated by broad chromosomal domains of transcriptional accessibility, marked by extensive occupancy of RNA polymerase II and H3K4me2; in a mutually exclusive way, by occupancy of PRC2 and H3K27me37. By the way of above, HOX genes can affect genes transcription by specifying the positional identities of chromosomes [43]. Aberrant expressions of HOX genes may affect cells differentiation and ontogeny, causing abnormal tissues and organs, and even contribute to a variety of tumors, such as ovarian cancer [44], gastric cancer [45], colorectal cancer [46, 47], neuroblastoma [48], kidney cancer [49], prostate cancers [50] and hematological malignancies $[51,52,53]$.

\section{HOX transcript antisense RNA}

HOTAIR is a long noncoding RNA 2158-nucleotides long, located on chromosome 12q13.13, and transcribed in an antisense manner with respect to the canonical HOXC genes. HOTAIR is highly conserved in primates and evolves faster than its neighbouring HoxC genes. Strand-specific RT-PCR analysis confirmed that only one strand of HOTAIR, antisense to HOXC genes, was transcribed. HOTAIR was preferentially expressed in posterior and distal sites. Computational analysis of HOTAIR secondary structure did not reveal obvious stem loops suggestive of pre-miRNAs. Northern blot analysis of sizefractionated RNA showed no evidence of small RNA products, which were suggestive of micro RNA or small interfering RNA (siRNA) production [7].

Figure 2 showes HOTAIR includes five short exons and a long exon. Different exons have different transition/ 
transversion rate ratio, different shape parameter of the gamma distribution and different nucleotide substitution rates between clades. All above indicate that different exons of HOTAIR have asynchronous evolution in mammals. Structure prediction vertified that the sequences and structures of the 5 ' end exon 1 and the 3 ' end domain B of exon 6 were highly conserved in mammals. It is considered that the two domains are the functional domains of HOTAIR, which can interact with polycomb protein and play a wide range of biological functions [54].

\section{Molecular mechanisms of HOTAIR}

Rinn et al [7] investigated the function of HOTAIR and found that siRNA-mediated depletion of HOTAIR had little effect on the transcription of HOXC locus on chromosome 12, while led to dramatic transcriptional activation of the HOXD locus on chromosome 2. Further study revealed depletion of HOTAIR resulted in loss of H3K27Me3 and Suz12 occupancy over the HOXD locus. Therefore, it was speculated that HOTAIR was selectively required to target PRC2 occupancy; thus, induced H3K27 trimethyation and silenced transcription of the HOXD locus. PRC2 first recruited to specific genomic locations to catalyze H3K27me3; methylated-H3K27 then served as a recognition site to further recruit PRC1; which in turn introduced H2AK119ub1 marks and impeded RNA polymerase II elongation $[55,56]$. EZH2 (enhancer of zeste homolog 2) was the catalytic subunit of PRC2, which directly attached on HOTAIR [57]. Its activity required binding to SUZ12 (suppressor of zeste 12) and EED (embryonic ectoderm development). In addition to PRC2,
Tsai et al [58] found that HOTAIR could also bind to LSD1. LSD1 was a demethylase which could form a complex with CoREST and REST, and mediated enzymatic demethylation of $\mathrm{H} 3 \mathrm{~K} 4 \mathrm{me} 2$. H3K4 demethylation was widely associated with transcriptional inactivation.

Chromatin Immunoprecipitation-chip (ChIP-chip) showed HOTAIR knockdown caused loss of SUZ12 and LSD1 occupancy in proximal promoters of HOXD genes; these regions correspondingly lost $\mathrm{H} 3 \mathrm{~K} 27 \mathrm{me} 3$ and gained $\mathrm{H} 3 \mathrm{~K} 4 \mathrm{me} 2$, the respective histone methylation products of PRC2 and LSD1 complexes. The loss of H3K27me3 occurred across broad domains encompassing multiple HOXD genes and intergenic regions, while the gain of $\mathrm{H} 3 \mathrm{~K} 4 \mathrm{me} 2$ was concentrated near the transcriptional start sites of HOXD genes. Utilizing a series of HOTAIR deletion mutants, the PRC2 binding activity mapped to the first $300 \mathrm{bp}$ of HOTAIR, while the LSD1 complex binding activity mapped to the last $646 \mathrm{bp}$. Therefore, a commonly recognized molecular mechanisms of HOTAIR is that the 5 ' domain of HOTAIR can bind to PRC2, while the 3' domain of HOTAIR can bind to the LSD1/CoREST/REST complex; after that, the complexes are targeted and assembled to the HOXD locus; and coordinately regulate histone $\mathrm{H} 3 \mathrm{~K} 27$ methylation and histone H3K4 demethylation; consequently, the transcription across $40 \mathrm{~kb}$ of the HOXD locus is silenced in trans by DNA methylation Figure 3. In addition to HOXD locus, Tsai et al also analyzed the genome-wide promoter occupancy of PRC2 and LSD 1 complexes, and uncovered that 721 promoters were targeted by both complexes. $40 \%$ of these promoters (289) displayed a corresponding loss of PRC2 and LSD1 occupancy in response to HORAIR knockdown. These results indicated

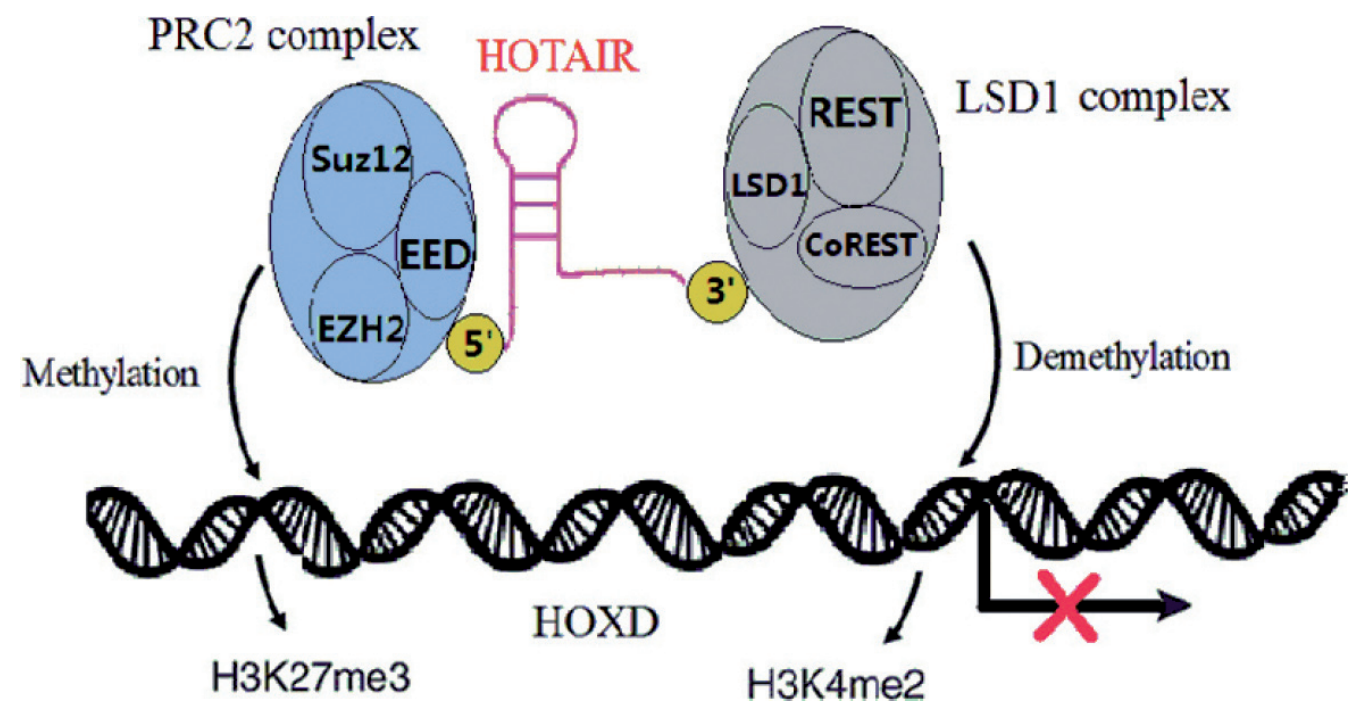

Figure 3. The mechanism of HOTAIR-mediated gene silencing.

PRC2 and LSD1-CoREST complexes bind to the $5^{\prime}$ and 3' portions of HOTAIR respectively. The resulting molecular complex is bound to the HOXD locus; coordinately regulate the histone modifications H3K27me3 trimethylation and H3K4me2 demethylation; which in turn, silence expression of the target genes. 
Table 1. Related cancers and potential functions of HOTAIR.

\begin{tabular}{|c|c|c|}
\hline Cancer & Potential functions of HOTAIR & References \\
\hline Breast Cancer & $\begin{array}{l}\text { In MCF7 cells, HOTAIR expression was associated with } \mathrm{Bcl} 2 \text { and BID expression, which contribute to cytochrome } \\
\mathrm{c} \text { release and apoptotic cell death. Over expression of HOTAIR induced localization of PRC2 on } 854 \text { new genes, } \\
\text { subsequently changed these gene expressions. Part of these genes are associated with inhibiting breast cancer } \\
\text { progression, including HOXD10, PRG1, PCDH, JAM2 and EPHA1. }\end{array}$ & $38,59,67,68$ \\
\hline Colorectal Cancer & Upregulated expression of HOTAIR induced SUZ12, H3K27me3, EZH2 and PRC2 occupancy in CRCs. & 40 \\
\hline Hepatocellular Cancer & $\begin{array}{l}\text { Knockdown of HOTAIR reduced the levels of MMP-9 and VEGF, which play important roles in cell motility and } \\
\text { metastasis. }\end{array}$ & $39,69,70$ \\
\hline Gastric Cancer & $\begin{array}{l}\text { Expression of HOTAIR in gastric cancer was associated with dysregulation of some EMT (epithelial- mesenchymal } \\
\text { transition) related genes and metastasis related genes (ICAM-1, MMP1, MMP3, MMP9), as well as expression of } \\
\text { snail, a transcription factor (TF) involved in various EMT processes. }\end{array}$ & $71,72,73$ \\
\hline $\begin{array}{l}\text { Gastrointestinal Stromal } \\
\text { Tumor }\end{array}$ & $\begin{array}{l}\text { Gene expression microarray analysis revealed that a total of 1,424 genes were upregulated by HOTAIR siRNA, } \\
\text { including PCHD10, SEMA6A, STK17B. }\end{array}$ & 74 \\
\hline Pancreatic Cancer & $\begin{array}{l}\text { HOTAIR expression regulated some significant gene sets in Panc1 cells, which were related to the cell cycle } \\
\text { progression and viability. Knockdown of PRC2 components (EZH2 and Suz12) as well as HOTAIR in Panc1 and } \\
\text { L3.6pL cells similarly induced expression of GDF15, which is a growth inhibitory gene. }\end{array}$ & 41,75 \\
\hline Lung Cancer & $\begin{array}{l}\text { HOTAIR expression was associated with the levels of matrix metalloproteinases (MMP2, MMP9) and HOXA5. } \\
\text { MMPs are involved in degrading the extracellular matrix (ECM) and HOXA5 is involved in NSCLC cell } \\
\text { migration and invasion. }\end{array}$ & $78,79,81$ \\
\hline $\begin{array}{l}\text { Laryngeal Squamous } \\
\text { Cell Carcinoma }\end{array}$ & $\begin{array}{l}\text { Promoter methylation analysis suggested that HOTAIR was involved in regulating PTEN methylation in Hep- } 2 \\
\text { cells, which may be a potential oncogenic mechanism of HOTAIR in LSCC. }\end{array}$ & 82 \\
\hline $\begin{array}{l}\text { Nasopharyngeal } \\
\text { Carcinoma }\end{array}$ & $\begin{array}{l}\text { HOTAIR expression was associated with the invasive potential of cells, and cells with high invasive potential } \\
\text { (5-8F, S18, CEN2) appeared higher expression levels of HOTAIR than cells with low invasive potential (6-10B, } \\
\text { S26, CNE1). }\end{array}$ & 83 \\
\hline $\begin{array}{l}\text { Esophageal Squamous } \\
\text { Cell Carcinoma }\end{array}$ & $\begin{array}{l}\text { HOTAIR reprogrammed the gene expression profile of ESCC cells, including genes involved in cell migration } \\
\text { and cell cycle. }\end{array}$ & 84,86 \\
\hline Endometrial Carcinoma & $\begin{array}{l}\text { A higher HOTAIR expression appeared correlated with the depth of myometrial invasion and lymphovascular } \\
\text { space invasion. }\end{array}$ & 85 \\
\hline Mesenchymal Glioma & $\begin{array}{l}\text { HOTAIR expression was associated with gene sets involved in cell cycle progression. HOTAIR reduction induced } \\
\text { colony formation suppression, cell cycle G0/G1 arrest, and orthotopic tumor growth inhibition. }\end{array}$ & 88 \\
\hline Melanoma & $\begin{array}{l}\text { Knockdown of HOTAIR suppressed the degradation of gelatin matrix, which is associated with tumor cell } \\
\text { invasion. }\end{array}$ & 89 \\
\hline
\end{tabular}

that HOTAIR-mediated assembly and targeting of PRC2 and LSD1 complexes could be a general mechanism for gene silencing across the genome.

\section{Breast cancer}

It was detected by qRT-PCR (quantitative real-time PCR) that in primary breast tumors and metastases, HOTAIR was over expressed from hundreds to nearly two thousand- fold than normal breast epithelia Figure 4. Multivariate analysis showed that HOTAIR was an independent mark for prognostic stratification of metastasis and death, besides known clinical risk factors such as tumor size, stage and hormone receptor status. Enforced expression of HOTAIR in four different breast cancer cells (MCF-10, MCF-7, SK-BR3, MDA-MB-231) could increase cell invasion through matrigel. HOTAIR-expressing in MDA-MB-231 cells increased the rate of primary tumor growth in vivo; moreover, it enhanced metastasis to lung. Conversely, HOTAIR siRNAs in MCF7 decreased its invasiveness
[38]. Bhan [59] and colleagues found that HOTAIR knockdown in MCF7 cells resulted in upregulation of Bcl2 and BID expression, which contributed to cytochrome $c$ release [60] and apoptotic cell death [61]. Further study demonstrated that HOTAIR expression was an estrogen-responsive gene expression and could be induced by E2 via estrogen receptors (ERs) and ER coactivators. ChIP-chip observed that overexpression of HOTAIR induced localization of PRC2 on 854 new genes, subsequently changed these gene expressions. Part of these genes were verified associated with inhibiting breast cancer progression, including HOXD10 [62], PRG1, PCDH [63], JAM2 [64] and EPHA1 [65, 66]. Another study found that both HOTAIR and EZH2 appeared highly expressed in the breast cancer metastasis; and co-expression of HOTAIR and EZH2 was prone to a worse outcome [67]. In addition, Lu et al [68] analyzed HOTAIR expression and DNA methylation in tissues from 348 primary breast cancers, and found heterogeneous expression of HOTAIR in primary breast cancer, which was consistent with previous reports. However, they did not find 


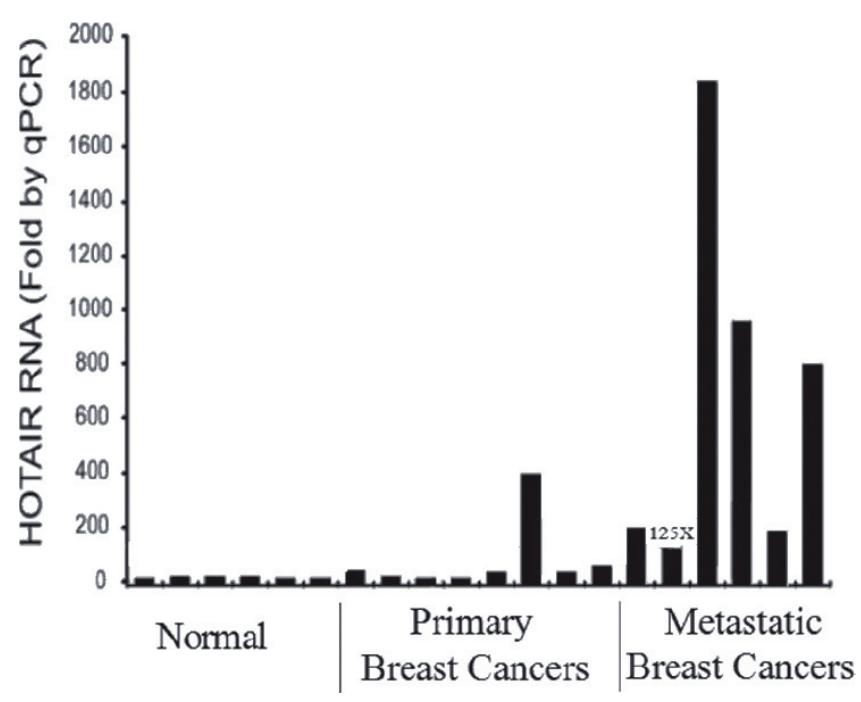

Figure 4. qRT-PCR of HOTAIR abundance in normal breast epithelia and breast cancers.

Metastatic cancers had a minimum 125-fold higher level of HOTAIR than normal breast

Epithelia (Figure modified from Ref 38).

significant associations of HOTAIR expression with clinical or pathologic characteristics. Interestingly, in multivariate analyses with the control of other clinical characteristics and therapy status, patients with high levels of HOTAIR expression had lower risks of relapse and death than those with low expression. This result indicated that clinicopathological features and therapy treatments could modify the effect of HOTAIR. Based on the above findings, it is considered that HOTAIR can be used as an independent predictor of breast cancer metastasis and prognosis, but it still needs further verification, and the interdependence between HOTAIR and PRC2 may be able to serve as a potential target for the treatment of breast cancer.

\section{Colorectal cancer}

In colorectal cancers (CRCs), HOTAIR expression was also higher in cancerous tissues than corresponding noncancerous ones, and HOTAIR expression was associated with the clinical and pathological manifestations. Moreover, high HOTAIR expression showed significantly more inclined to liver metastasis and poorer prognosis [40]. GSEA based on cDNA microarray showed upregulated expression of HOTAIR similarly induced SUZ12, H3K27me3, EZH2, and PRC2 occupancy as in breast cancers Figure 5.

\section{Hepatocellular cancer}

The expression levels of HOTAIR in 4 kinds of liver cancer cell lines (SMMC-7721, HepG2, Bel-7402, HCCLM3)

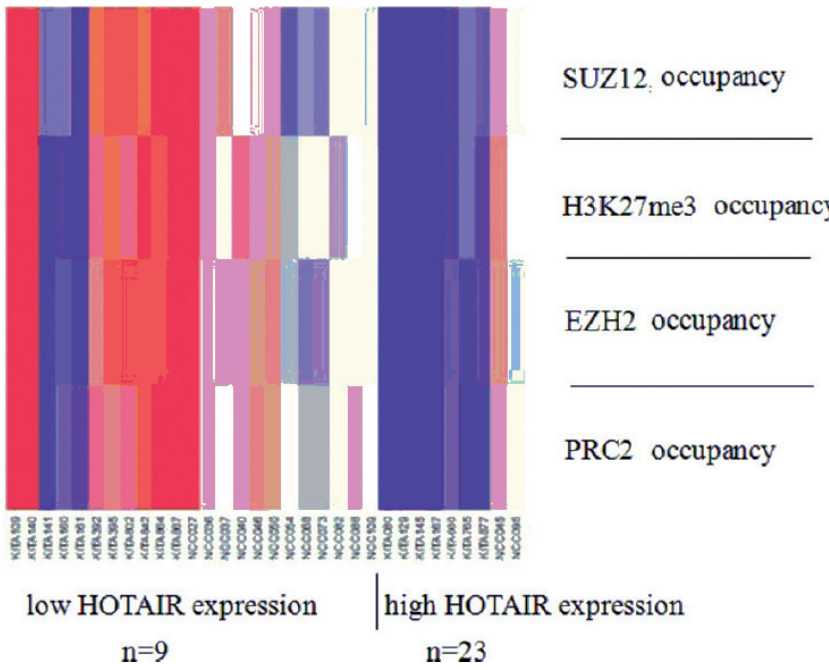

Figure 5. Heat map of the gene expression averages for 32 CRC samples. The enriched gene expression averages were classified by high and low HOTAIR expression levels. Enriched gene expression signatures of $\mathrm{HO}-$ TAIR-induced SUZ12, H3K27me3, EZH2, and PRC2 occupancy were described by red and blue colors. The red and blue colors indicate high and low expression, respectively (Figure modified from Ref 40).

were detected higher than normal liver cell lines; and paired primary tumor tissues exhibited higher HOTAIR expression than adjacent nontumorous ones [39]. Moreover, overexpression of HOTAIR in HCC patients was associated with lower 3-year cumulative recurrence-free survival and shorter recurrence-free survival after LT in HCCs. Knockdown of HOTAIR significantly decreased HepG2 cells viability and invasiveness, and increased susceptibility to apoptotic stimuli TNF-a as well as chemotherapeutic drug cisplatin and doxorubicin. It indicated that HOTAIR could be a therapeutical target to improve clinical therapies. HOTAIR expression was also associated with lymph node metastasis and tumor size in HCC patients [69]. Knockdown of HOTAIR reduced the levels of MMP-9 and VEGF [70], which play important roles in cell motility and metastasis. Gene set enrichment analysis (GSEA) showed the expression profiles of localization of $\mathrm{H} 3 \mathrm{~K} 27 \mathrm{me} 3$ and EZH2 were not significantly associated with HOTAIR expression in HCCs, unlike that noted in breast and colorectal cancers; however, this outcome needed to be further confirmed.

\section{Gastric cancer}

Endo [71] and colleagues, using qRT-PCR, discovered that HOTAIR expression were significantly higher in carcinoma lesions compared to non-cancerous lesions in gastric cancer patients Figure 6. High HOTAIR expression was associated with tumor stage, lymph node metastasis, venous invasion and poor survival [72]. Moreover, the anchorage-independent growth and peritoneal dissemi- 

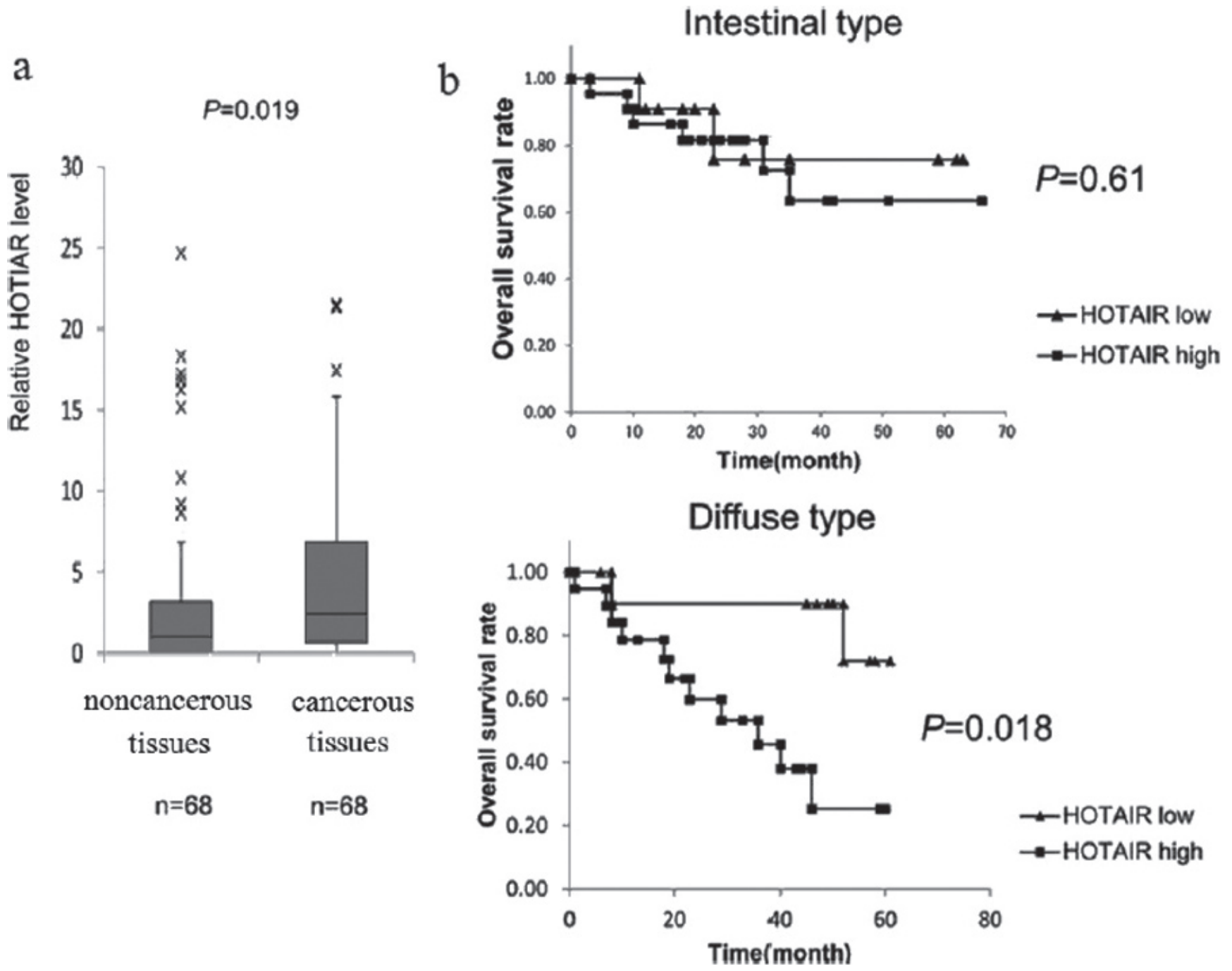

Figure 6. Relative HOTAIR level in cancerous and adjacent noncancerous tissues.

(a) The HOTAIR expression levels of cancerous and adjacent noncancerous tissues from the gastric cancer patients were examined by qRT-PCR and normalized by the GAPDH expression level. The expression levels of HOTAIR were significantly higher in carcinoma tissues compared to those of non-cancerous tissues. (b) The overall survival between high and low HOTAIR expression groups in intestinal and diffuse types of gastric cancer. A significantly short overall survival was found in the diffuse type gastric cancer (Figure modified from Ref 71).

nation of gastric cancer were promoted by overexpression of HOTAIR but inihibited when HOTAIR expression was knockdown by its targeted shRNA (shHOTAIR). Similar conclusions were reported by $\mathrm{Xu}$ [73] and co-workers, they found that some EMT (epithelial- mesenchymal transition ) related genes as well as some metastasis related genes (ICAM-1, MMP1, MMP3, MMP9) were misregulated in gastric cancer with high expression of HOTAIR. Further study discovered that deletion of HOTAIR could reverse EMT and the expression of snail, which decreased markedly when HOTAIR knockdown. Snail is a transcription factor (TF) involved in various EMT processes. The invasiveness of gastric cancer cell suppressed by HOTAIR siRNA could be restored by exogenous snail, and the EMT reversed by HOTAIR knockdown could also be restored by exogenous snail expression.

\section{Gastrointestinal stromal tumor and pancreatic cancer}

It was reported that over expression of HOTAIR was associated with high-risk grade, metastasis and poor overall survival in gastrointestinal stromal tumor (GIST) and pancreatic cancer patients [74, 75]. Kim [41] and colleagues found knocking down HOTAIR expression increased expression of 454 genes and decreased expression of 552 genes in pancreatic cancer cell line, including 
20 significant gene sets in Pancl cells, 10 of which were related to the cell cycle progression and viability. In GIST cells, a total of 1,424 genes were upregulated by HOTAIR siRNA ( $>2$-fold), including a number of reported HOTAIR target genes (PCHD10, SEMA6A, STK17B) [75]. In additiona, comparison of the genes induced or repressed by HOTAIR knockdown or overexpression in Panc1 cells and MDA-MB-231 cells showed that HOTAIR regulated significantly different sets of genes in these two cells. Moreover, study found that knockdown of PRC2 components (EZH2 and Suz12), as well as knockdown of HOTAIR in Panc1 and L3.6pL cells similarly induced expression of GDF15, which is a growth inhibitory gene [76, 77]. ChIP analysis showed that primers directed at the proximal region of the GDF15 promoter detected H3K27 trimethylation and EZH2 binding but not RNA pol II interactions in Panc1 cells transfected with control siRNA; In contrast, knockdown of HOTAIR by RNA interference resulted in the loss of H3K27 trimethylation and EZH2 binding but increased interaction of RNA pol II with the GDF15 promoter region [41]. Transfection of HOTAIR siRNA affected invasiveness and apoptosis of Panc1 and L3.6pL cells, and inhibited the volume and weight growth of tumors in a murine xenograft model.

\section{Lung cancer}

In non-small cell lung cancers (NSCLCs), paired NSCLC tissues were detected higher HOTAIR expression than adjacent non-tumor ones. Overexpressed HOTAIR was associated with advanced pathological stage, lymph-node metastasis and shorter survival time. In addition, inhibiting HOTAIR expression increased the apoptosis and decreased the migration and invasion of NSCLC cells in vitro [78].
A similar result was reported recently by Nakagawa [79] and colleagues. Further study found that HOTAIR knockdown was associated with levels of matrix metalloproteinases (MMP2, MMP9) as well as expression of HOXA5. MMPs are involved in degrading the extracellular matrix (ECM). And HOXA5 is involved in NSCLC cell migration and invasion [80]. Another study by Zhuang [81] and co-workers found that, in the human lung adenocarcinoma cell line, HOTAIR was induced by Col-1 (type I collagen), a composition of interstitial extracellular matrix (ECM) which aberrantly increased in the tumor microenvironment. However, there was no significant quantitative correlation between $\mathrm{HO}$ TAIR and Col-1 in NSCLC cells, besides both overall upward trend. It is proposed the upregulation of HOXA5 and MMPs may be a carcinogenic mechanism of HOTAIR in Lung Cancer.

\section{Laryngeal squamous cell carcinoma and nasopharyngeal carcinoma}

In laryngeal squamous cell carcinomas (LSCCs) and nasopharyngeal carcinomas (NPCs), HOTAIR expression of tumor tissues was higher than adjacent nonneoplastic ones. HOTAIR expression levels were significantly associated with tumor size, clinical stage, lymph node and distant metastasis; and affected the overall survival and prognosis of cancer patients $[82,83]$. HOTAIR knockdown inhibited the invasion of Hep-2 cells, and induced the apoptosis of Hep-2 cells. Moreover, study found cells with high invasive potential (5-8F, S18, CEN2) appeared higher expression levels of HOTAIR than cells with low invasive potential (6-10B, S26, CNE1). In a xenograft mice model, HOTAIR siRNA reduced the weight growth of LSCC. Promoter methylation analysis suggested

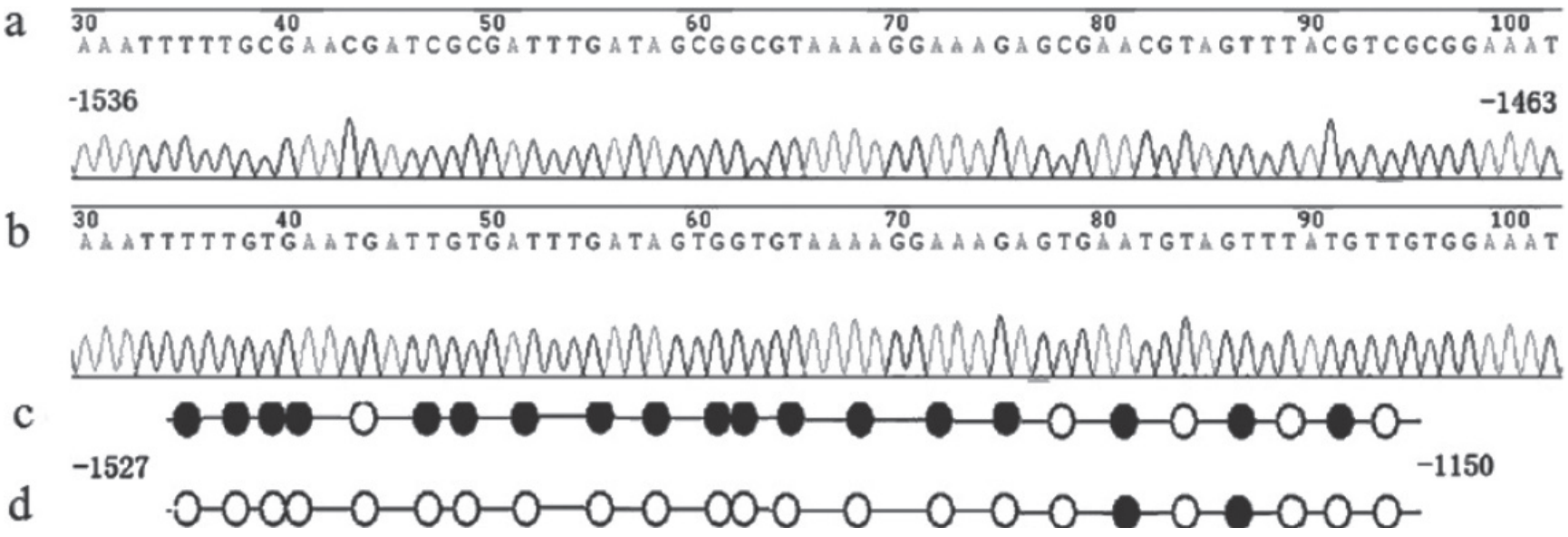

Figure 7. Methylation of the human PTEN promoter in Hep-2 cells.

(a) Representative results of bisulfite sequencing for control Hep-2 cells. (b) Hep-2 cells infected with HOTAIR siRNA lentivirus. (c) Methylation mapping of $23 \mathrm{CpG}$ sites of the PTEN promoter region obtained from bisulfite sequencing in control Hep-2 cells. (d) Methylation mapping in Hep-2 cells infected with HOTAIR siRNA. Black circles, methylated; white circles, unmethylated (Figure modified from Ref 82). 

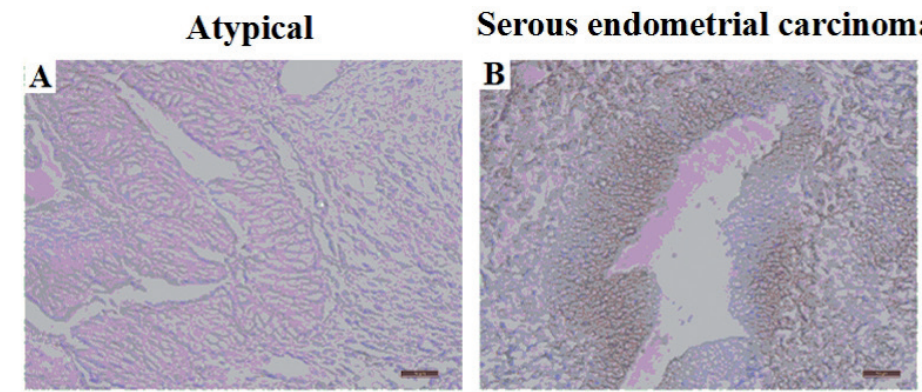
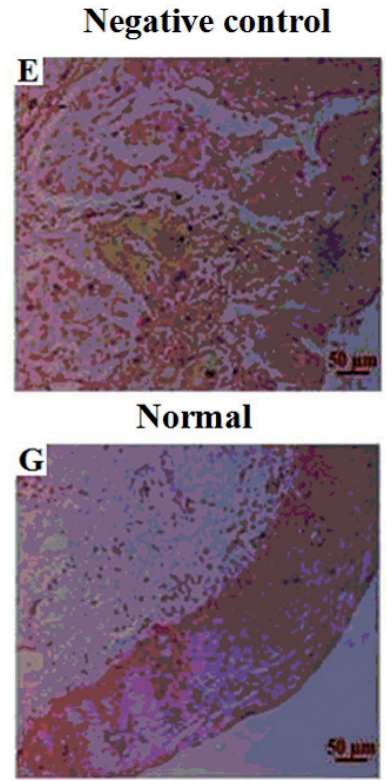

Normal lymph node

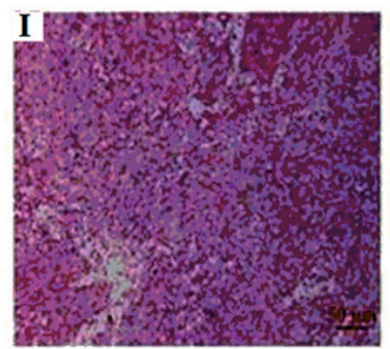

Positive control

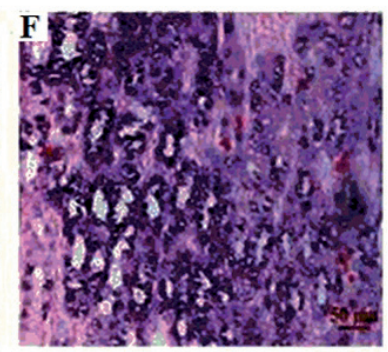

Cancer

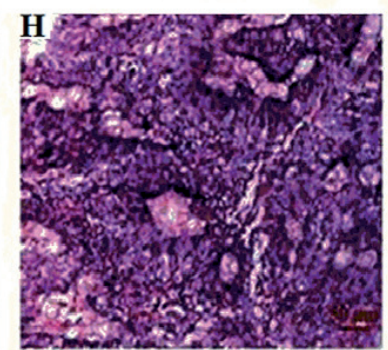

Metastatic lymph node

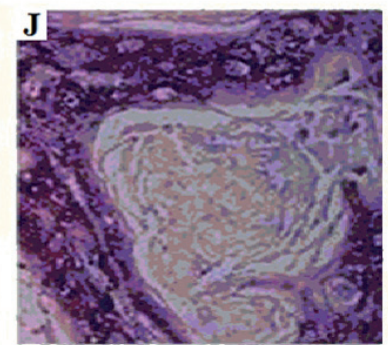

Figure 8. Representative images of in situ hybridization for HOTAIR in EC and ESCC.

Representative images of in situ hybridization for HOTAIR in normal endometrial (A), atypical (B), serous endometrial carcinoma (C) and endometrioid carcinoma tissues (D); in negative control (E), positive control (F), non-ESCC tissue (G), ESCC tissue (H), normal lymph node (I) and metastatic lymph node (J) (Figures modified from Ref 84 and 85 ).

that HOTAIR was involved in regulating PTEN methylation in Hep- 2 cells Figure 7, which might be a potential oncogenic mechanism of HOTAIR in LSCC.

\section{Esophageal squamous cell carcinoma and endometrial carcinoma}

In situ hybridization revealed that HOTAIR expression in the tumor tissues was significantly upregulated compared with normal tissues in esophageal squamous cell carcinomas (ESCCs) and endometrial carcinomas (ECs) Figure 8. Kaplan-Meier and Cox regression analyses showed that expression level of HOTAIR was associated with the clinicopathologic parameters in ESCCs [84]. And a significant association between HOTAIR expression with the EC grade, lymph node metastasis and overall survival was observed in ECs [85]. In the formalin-fixed paraffin-embedded
(FFPE) tissue, but not the frozen tissues, a higher HOTAIR expression appeared correlated with the depth of myometrial invasion and lymphovascular space invasion. Moreover, HOTAIR mediated the proliferation, colony formation and migratory capacity of ESCC cells in vitro. HOTAIR reprogrammed the gene expression profile of ESCC cells, including genes involved in cell migration and cell cycle. [86]. Silencing the expression of HOTAIR in ESCC cells could suppress the tumor growth in both size and weight in a mouse xenograft model [87].

\section{Mesenchymal glioma}

Zhang et al [88] analyzed the clinical significance and function of HOTAIR in glioma, and found that HOTAIR expression was closely related to glioma grade, prognosis and glioma molecular subtype. Multivariate Cox regression analysis revealed that HOTAIR was an independent prognostic factor 


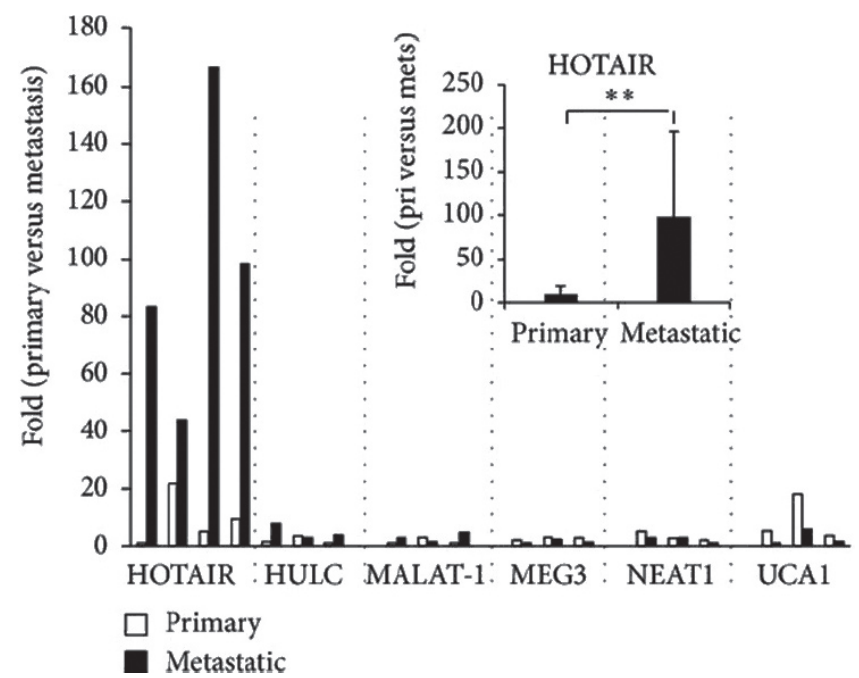

Figure 9. Expression profiles of lncRNAs in melanoma and matched lymph node metastatic tissues. Among the tested IncRNAs, HOTAIR was the most highly expressed in lymph node metastasis tissues of melanoma (Figure modified from Ref 89).

in glioblastoma multiforme patients. A gene set enrichment analysis between mesenchymal glioma patients with high and low HOTAIR expression showed that HOTAIR expression was associated with gene sets involved in cell cycle progression. In addition, HOTAIR reduction induced colony formation suppression, cell cycle G0/G1 arrest and orthotopic tumor growth inhibition. In summary, it was suggested that HOTAIR could serve as a prognostic factor for glioma patients, as well as a biomarker for identifying glioma molecular subtypes.

\section{Melanoma}

Tang et al [89] investigated the role of 6 metastasis-related lncRNAs ( HOTAIR, HULC, MALAT1, MEG3, NEAT1 and UCA1) in 3 pairs of primary melanoma and matched lymph node metastatic tissues by qRT-PCR. Among the tested lncRNAs, HOTAIR was the most highly expressed in lymph node metastasis Figure 9. Knockdown of HOTAIR resulted in the reduction of motility and invasion of human melanoma cell line A375. In addition, HOTAIR knockdown suppressed the degradation of gelatin matrix, which was involved in tumor cell invasion. These data indicated that HOTIAR might be associated with the metastasis of melanoma.

\section{Conclusion and future perspectives}

In summary, with HOTAIR becomes a hot topic, more and more studies about the relevance of HOTAIR with cancers have been reported. It has been demonstrated that anomalous expression of HOTAIR appeared associated with a wide range of cancer characteristics, such as apoptosis, proliferation and invasiveness of tumor cells; and HOTAIR expression affected the survival and prognosis of cancer patients. The molecular mechanisms of HOTAIR in cancer progression involve in recruiting PRC2 and LSD1 complexes, H3K27 methylation and H3K4 demethylation, and ultimately gene silencing. However, the precise mechanism of how dysregulated HOTAIR expressions drive cancer progression is not yet fully understood. It is also unclear whether other components of PRC2 and LSD1 complexes affect their interactions with HOTAIR; whether HOTAIR interacts with additional chromatin-modifying enzymes through other molecular mechanisms; Furthermore, whether HOTAIR could be a molecular mark for diagnosis or prognosis of cancers and serve as a therapeutic target to cancer progression. All of these require further investigation.

\section{References}

[1] OKAZAKI Y, FURUNO M, KASUKAWA T, ADACHI J, $\mathrm{BONO} \mathrm{H}$, et al. Analysis of the mouse transcriptome based on functional annotation of 60,770 full-length cDNAs. Nature 2002; 420: 563-573. http://dx.doi.org/10.1038/ nature 01266

[2] CARNINCI P, KASUKAWA T, KATAYAMA S, GOUGH J, FRITH MC, et al. The transcriptional landscape of the mammalian genome. Science 2005; 309: 1559-1563. http://dx.doi. org/10.1126/science.1112014

[3] KATAYAMA S, TOMARU Y, KASUKAWA T, WAKI K, NAKANISHI M, et al. Antisense transcription in the mammalian transcriptome. Science 2005; 309: 1564-1566. http://dx.doi. org/10.1126/science.1112009

[4] STRUHL K. Transcriptional noise and the fidelity of initiation by RNA polymerase II. Nature structural \& molecular biology 2007; 14: 103-105. http://dx.doi.org/ 10.1038/nsmb0207-103

[5] WANG J, ZHANG J, ZHENG H, LI J, LIU D, et al. Mouse transcriptome: neutral evolution of ,non-coding'complementary DNAs. Nature 2004; 431: 1 p following 757; discussion following 757.

[6] PONJAVIC J, PONTING C P, LUNTER G. Functionality or transcriptional noise? Evidence for selection within long noncoding RNAs. Genome research 2007; 17: 556-565. http:// dx.doi.org/10.1101/gr.6036807

[7] RINN JL, KERTESZ M, WANG JK, SQUAZZO SL, XU $\mathrm{X}$, et al. Functional demarcation of active and silent chromatin domains in human HOX loci by noncoding RNAs. Cell 2007; 129: 1311-1323. http://dx.doi.org/10.1016/ j.cell.2007.05.022

[8] DINGER ME, AMARAL PP, MERCER TR, PANG KC, BRUCE SJ, et al. Long noncoding RNAs in mouse embryonic stem cell pluripotency and differentiation. Genome research 2008; 18: 1433-1445. http://dx.doi.org/10.1101/ gr.078378.108

[9] RAVASI T, SUZUKI H, PANG KC, KATAYAMA S, FURUNO $\mathrm{M}$, et al. Experimental validation of the regulated expression of large numbers of non-coding RNAs from the mouse genome. Genome research 2006; 16: 11-19. http://dx.doi.org/10.1101/ gr.4200206 
[10] MERCER TR, DINGER ME, SUNKIN SM, MEHLER MF, MATTICK JS. Specific expression of long noncoding RNAs in the mouse brain. Proceedings of the National Academy of Sciences 2008; 105: 716-721. http://dx.doi.org/10.1073/ pnas.0706729105

[1] PANG KC, DINGER ME, MERCER TR, MALQUORI L, GRIMMOND SM, et al. Genomewide identification of long noncoding RNAs in CD8+ T cells. The Journal of Immunology 2009; 182: 7738-7748. http://dx.doi.org/10.4049/ jimmunol.0900603

[12] SUNWOO H, DINGER ME, WILUSZ JE, AMARAL PP, MATTICK JS, et al. MEN epsilon/beta nuclear-retained non-coding RNAs are up-regulated upon muscle differentiation and are essential components of paraspeckles. Genome research 2009; 19: 347-359. http://dx.doi.org/10.1101/ gr.087775.108

[13] SASAKI YT, IDEUE T, SANO M, MITUYAMA T, HIROSE T. MEN epsilon/beta noncoding RNAs are essential for structural integrity of nuclear paraspeckles. Proc Natl Acad Sci USA 2009; 106: 2525-2530. http://dx.doi.org/10.1073/ pnas.0807899106

[14] CLEMSON CM, HUTCHINSON JN, SARA SA, ENSMINGER AW, FOX AH, et al. An architectural role for a nuclear noncoding RNA: NEAT1 RNA is essential for the structure of paraspeckles. Mol Cell 2009; 33: 717-726. http:// dx.doi.org/10.1016/j.molcel.2009.01.026

[15] TIAN D, SUN S, LEE JT. The long noncoding RNA, Jpx, is a molecular switch for X chromosome inactivation. Cell 2010; 143: 390-403. http://dx.doi.org/10.1016/j.cell.2010.09.049

[16] MATTICK JS, AMARAL PP, DINGER ME, MERCER TR, MEHLER MF. RNA regulation of epigenetic processes. Bioessays 2009; 31: 51-9. http://dx.doi.org/10.1002/bies.080099

[17] NOWACKI M, VIJAYAN V, ZHOU Y, SCHOTANUS K, DOAK TG, et al. RNA-mediated epigenetic programming of a genome- rearrangement pathway. Nature 2007; 451: 153-158. http://dx.doi.org/10.1038/nature06452

[18] KHALIL AM, GUTTMAN M, HUARTE M, GARBER M, RAJ A, et al. Many human large intergenic noncoding RNAs associate with chromatin-modifying complexes and affect gene expression. Proc Natl Acad Sci 2009; 106: 11667-11672. http://dx.doi.org/10.1073/pnas.0904715106

[19] GUTTMAN M, AMIT I, GARBER M, FRENCH C, LIN MF, et al. Chromatin signature reveals over a thousand highly conserved large non-coding RNAs in mammals. Nature 2009; 458: 223-227. http://dx.doi.org/10.1038/nature07672

[20] MOHAMMAD F, PANDEY RR, NAGANO T, CHAKALOVA L, MONDAL T, et al. Kcnq1 ot1/Lit1 noncoding RNAmediates transcriptional silencing by targeting to the perinucleolarregion. Mol Cell Biol 2008; 28: 3713-3728. http://dx.doi. org/10.1128/MCB.02263-07

[21] PANDEY RR, MONDAL T, MOHAMMAD F, ENROTH $S$, REDRUP L, et al. Kcnq1ot1 antisense noncoding RNA mediates lineage-specific transcriptional silencing through chromatin-level regulation. Mol Cell 2008; 32: 232-246. http://dx.doi.org/10.1016/i.molcel.2008.08.022

[22] JEON Y, SARMA K, NEW LEE JT. Xisting regulatory mechanisms of $\mathrm{X}$ chromosomeinactivation. Current Opinion in
Genetics \& Development 2012; 22: 62-71. http://dx.doi. org/10.1016/j.gde.2012.02.007

[23] TRIPATHI V, ELLIS JD, SHEN Z, SONG DY, PAN Q, et al. The nuclear-retained noncoding RNA MALAT1 regulates alternative splicing by modulating SR splicing factor phosphorylation. Molecular cell 2010; 39: 925-2938. http://dx.doi. org/10.1016/j.molcel.2010.08.011

[24] WANG KC AND CHANG HY. Molecular mechanisms of long noncoding RNAs. Molecular cell 2011; 43: 904-2914. http://dx.doi.org/10.1016/j.molcel.2011.08.018

[25] CLARK M B AND MATTICK J S. Long noncoding RNAs in cell biology. Seminars in cell \& developmental biology 2011; 22: 366-376. http://dx.doi.org/10.1016/ j.semcdb.2011.01.001

[26] MORAN V A, PERERA R J, KHALIL A M. Emerging functional and mechanistic paradigms of mammalian long non-coding RNAs. Nucleic acids research. 2012; 40: 63916400. http://dx.doi.org/10.1093/nar/gks296

[27] KINO T, HURT D E, ICHIJO T,NADER N, CHROUSOS GP. Noncoding RNA gas 5 is a growth arrest-and starvation-associated repressor of the glucocorticoid receptor. Science signaling 2010; 3: ra8. http://dx.doi.org/10.1126/scisignal.2000568

[28] MOURTADA-MAARABOUNI M, HEDGE VL, KIRKHAM L, FARZANEH F, WILLIAMS GT. Growth arrest in human T-cells is controlled by the non-coding RNA growth-arrestspecific transcript 5 (GAS5). J Cell Sci 2008; 121: 939-946. http://dx.doi.org/10.1242/jcs.024646

[29] MOURTADA-MAARABOUNI M, PICKARD MR, HEDGE VL, FARZANEH F, WILLIAMS GT. GAS5, a non-proteincoding RNA, controls apoptosis and is downregulated in breast cancer. Oncogene 2009; 28: 195-208 http://dx.doi. org/10.1038/onc. 2008.373

[30] GIBB E A, BROWN C J, LAM W L. The functional role of long non-coding RNA in human carcinomas. Mol Cancer 2011; 10: 38-55. http://dx.doi.org/10.1186/1476-4598-10-38

[31] TSAI MC, SPITALE RC, CHANG HY. Long intergenic noncoding RNAs: new links in cancer progression. Cancer Res 2011; 71:3-7. http://dx.doi.org/10.1158/0008-5472.CAN-102483

[32] WANG KC AND CHANG HY. Molecular mechanisms of long noncoding RNAs. Mol Cell 2011; 43: 904-914. http://dx.doi. org/10.1016/j.molcel.2011.08.018

[33] HUARTE M, GUTTMAN M, FELDSER D, GARBER M, KOZIOL MJ, et al. A large intergenic noncoding RNA induced by $\mathrm{p} 53$ mediates global gene repression in the p53 response. Cell 2010; 142: 409-419. http://dx.doi.org/10.1016/ j.cell.2010.06.040

[34] GUTTMAN M AND RINN J L. Modular regulatory principles of large non-coding RNAs. Nature 2012; 482: 339-346. http://dx.doi.org/10.1038/nature10887

[35] DAVID R. Non-coding RNAS: A new member of the family. Nature Reviews Molecular Cell Biology 2012; 13: 686-686. http://dx.doi.org/10.1038/nrm3449

[36] SPITALE RC, TSAI MC, CHANG HY. RNA templating the epigenome: long noncoding RNAs as molecular scaffolds. Epigenetics 2011; 6: 539-543. http://dx.doi.org/10.4161/ epi.6.5.15221 
[37] YOON JH, ABDELMOHSEN K, KIM J, YANG X, MARTINDALE JL, et al. Scaffold function of long non-coding RNA HOTAIR in protein ubiquitination. Nature communications 2013; 4.

[38] GUPTA RA, SHAH N, WANG KC, KIM J, HORLINGS HM,et al. Long non-coding RNA HOTAIR reprograms chromatin state to promote cancer metastasis. Nature 2010; 464: 1071-1076. http://dx.doi.org/10.1038/nature08975

[39] YANG Z, ZHOU L, WU LM, LAI MC, XIE HY, et al. Overexpression of long non-coding RNA HOTAIR predicts tumor recurrence in hepatocellular carcinoma patients following liver transplantation. Ann Surg Oncol 2011; 18: 1243-1250. http://dx.doi.org/10.1245/s10434-011-1581-y

[40] KOGO R, SHIMAMURA T, MIMORI K, KAWAHARA K, IMOTO S, et al. Long noncoding RNA HOTAIR regulates polycomb- dependent chromatin modification and is associated with poor prognosis in colorectal cancers. Cancer Res 2011; 71: 6320-6326. http://dx.doi.org/10.1158/0008-5472. CAN-11-1021

[41] KIM K, JUTOORU I, CHADALAPAKA G, JOHNSON G, FRANK J, et al. HOTAIR is a negative prognostic factor and exhibits pro-oncogenic activity in pancreatic cancer. Oncogene 2012; 32: 1616-1625 http://dx.doi.org/10.1038/ onc. 2012.193

[42] LEWIS EB. A gene complex controlling segmentation in Drosophila. Nature 1978; 276: 565-570. http://dx.doi. org/10.1038/276565a 0

[43] DICKSON GJ, LAPPIN TR, THOMPSON A. Complete array of HOX gene expression by RQ-PCR. Methods Mol Biol 2009; 538: 369-393. http://dx.doi.org/10.1007/978-1-59745-418$\underline{619}$

[44] MORGAN R, PLOWRIGHT L, HARRINGTON KJ, MICHAEL A, PANDHA HS. Targeting HOX and PBX transcription factors in ovarian cancer. BMC Cancer 2010; 10: 89. http://dx.doi.org/10.1186/1471-2407-10-89

[45] HAN Y, TU WW, WEN YG, LI DP, QIU GQ, et al. Identification and validation that up-expression of HOXA13 is a novel independent prognostic marker of a worse outcome in gastric cancer based on immunohistochemistry. Medical Oncology 2013; 30: 1-9. http://dx.doi.org/10.1007/s12032013-0564-1

[46] WANG Y, HUNG C, KOH D, CHEONG D, HOOI SC. Differential expression of Hox A5 in human colon cancer cell differentiation: A quantitative study using real-time RT-PCR. International journal of oncology 2001; 18: 617-622.

[47] EE HC, ERLER T, BHATHAL PS, YOUNG GP, JAMES RJ. Cdx-2 homeodomain protein expression in human and rat colorectal adenoma and carcinoma. Am J Pathol 1995; 147: 586-592.

[48] PEVERALI FA, D'ESPOSITO M, ACAMPORA D, BUNONE G, NEGRI M, et al. Expression of HOX homeogenes in human neuroblastoma cell culture lines. Differentiation. 1990; 45: 61-69. http://dx.doi.org/10.1111/j.1432-0436.1990.tb00458.x

[49] CILLO C, BARBA P, FRESCHI G, BUCCIARELLI G, MAGLI $\mathrm{MC}$, et al. HOX gene expression in normal and neoplastic human kidney. International journal of cancer 1992; 51: 892-897. http://dx.doi.org/10.1002/ijc.2910510610
[50] BOWEN C, BUBENDORF L, VOELLER HJ, SLACK R, WILLI $\mathrm{N}$, et al. Loss of NKX3. 1 expression in human prostate cancers correlates with tumor progression1, 2. Cancer research 2000; 60: 6111-6115.

[51] ABATE-SHEN C. Deregulated homeobox gene expression in cancer: cause or consequence? Nat Rev Cancer 2002; 2: 777-785. http://dx.doi.org/10.1038/nrc907

[52] SAMUEL S AND NAORA H. Homeobox gene expression in cancer: insights from developmental regulation and deregulation. Eur J Cancer 2005; 41: 2428-2437. http://dx.doi. org/10.1016/j.ejca.2005.08.014

[53] ARGIROPOULOS B AND HUMPHRIES RK. Hox genes in hematopoiesis and leukemogenesis. Oncogene 2007; 26: 6766-776. http://dx.doi.org/10.1038/sj.onc. 1210760

[54] HE S, LIU S, ZHU H. The sequence, structure and evolutionary features of HOTAIR in mammals. BMC evolutionary biology 2011; 11: 102. http://dx.doi.org/10.1186/1471-214811-102

[55] MOREY L AND HELIN K. Polycomb group protein-mediated repression of transcription. Trends Biochem Sci 2010; 35: 323-332. http://dx.doi.org/10.1016/j.tibs.2010.02.009

[56] SAUVAGEAU M AND SAUVAGEAU G. Polycomb group proteins: multi-faceted regulators of somatic stem cells and cancer. Cell Stem Cell 2010; 7: 299-313. http://dx.doi. org/10.1016/j.stem.2010.08.002

[57] KANEKO S, LI G, SON J, XU CF, MARGUERON R, et al. Phosphorylation of the PRC2 component Ezh2 is cell cycleregulated and up-regulates its binding to ncRNA. Genes \& development 2010; 24: 2615-2620. http://dx.doi.org/10.1101/ gad.1983810

[58] TSAI MC, MANOR O, WAN Y, MOSAMMAPARAST N, WANG JK, et al. Long noncoding RNA as modular scaffold of histone modification complexes. Science 2010; 329: 689-693. http://dx.doi.org/10.1126/science.1192002

[59] BHAN A, HUSSAIN I, ANSARI KI, KASIRI S, BASHYAL A, et al. Antisense Transcript Long Noncoding RNA (lncRNA) HOTAIR is Transcriptionally Induced by Estradiol. Journal of molecular biology 2013; 425: 3707-3722. http://dx.doi. org/10.1016/j.jmb.2013.01.022

[60] LI H, ZHU H, XU CJ, YUAN J. Cleavage of BID by caspase 8 mediates the mitochondrial damage in the Fas pathway of apoptosis. Cell 1998; 94: 491-501. http://dx.doi.org/10.1016/ S0092-8674(00)81590-1

[61] WALL NR, MOHAMMAD RM, AL-KATIB AM. Bax: Bcl-2 ratio modulation by bryostatin 1 and novel antitubulin agents is important for susceptibility to drug induced apoptosis in the human early pre-B acute lymphoblastic leukemia cell line, Reh. Leukemia research 1999; 23: 881-888. http://dx.doi. org/10.1016/S0145-2126(99)00108-3

[62] MA L, TERUYA-FELDSTEIN J, WEINBERG RA. Tumour invasion and metastasis initiated by microRNA-10b in breast cancer. Nature 2007; 449: 682-688. http://dx.doi.org/10.1038/ nature06174

[63] NOVAK P, JENSEN T, OSHIRO MM, WATTS GS, KIM CJ, et al. Agglomerative epigenetic aberrations are a common event in human breast cancer. Cancer research 2008; 68: 8616-8625. http://dx.doi.org/10.1158/0008-5472.CAN-08-1419 
[64] NAIK MU, NAIK TU, SUCKOW AT, DUNCAN MK, NAIK UP. Attenuation of junctional adhesionmolecule-A is a contributing factor for breast cancer cell invasion. Cancer research 2008; 68: 2194-2203. http://dx.doi.org/10.1158/0008-5472. CAN-07-3057

[65] FOX BP, KANDPAL RP. Invasiveness of breast carcinoma cells and transcript profile: Eph receptors and ephrin ligands as molecular markers of potential diagnostic and prognostic application. Biochemical and biophysical research communications 2004; 318: 882-892. http://dx.doi. org/10.1016/j.bbrc.2004.04.102

[66] HERATH NI, DOECKE J, SPANEVELLO MD, LEGGETT BA, BOYD AW. Epigenetic silencing of EphA1 expression in colorectal cancer is correlated with poor survival. British journal of cancer 2009; 100: 1095-1102. http://dx.doi. org/10.1038/sj.bjc.6604970

[67] CHISHOLM KM, WAN Y, LI R, MONTGOMERY KD, CHANG HY, et al. Detection of long non-coding RNA in archival tissue:correlation with polycomb protein expression in primary and metastatic breast carcinoma. PLoS One 2012; 7:e47998. http://dx.doi.org/10.1371/journal.pone.0047998

[68] LU L, ZHU G, ZHANG C, DENG Q, KATSAROS D,et al. Association of large noncoding RNA HOTAIR expression and its downstream intergenic $\mathrm{CpG}$ island methylation with survival in breast cancer. Breast Cancer Res Treat 2012; 136875-883.

[69] ISHIBASHI M, KOGO R, SHIBATA K, SAWADA G, TAKAHASHI Y, et al. Clinical significance of the expression of long non-coding RNA HOTAIR in primary hepatocellular carcinoma. Oncol Rep 2013; 29: 946-950.

[70] GENG YJ, XIE SL, LI Q, MA J, WANG GY. Large intervening non-coding RNA HOTAIR is associated with hepatocellular carcinoma progression. J Int Med Res 2011; 39: 2119-2128. http://dx.doi.org/10.1177/147323001103900608

[71] ENDO H, SHIROKI T, NAKAGAWA T, YOKOYAMA M, TAMAI K, et al. Enhanced Expression of Long Non-Coding RNA HOTAIR Is Associated with the Development of Gastric Cancer. PloS one 2013; 8:e77070. http://dx.doi.org/10.1371/ journal.pone.0077070

[72] HAJJARI M, BEHMANESH M, SADEGHIZADEH M, ZEINODDINI M. Up-regulation of HOTAIR long non-coding RNA in human gastric adenocarcinoma tissues. Medical Oncology 2013; 30: 1-4. http://dx.doi.org/10.1007/s12032013-0670-0

[73] XU ZY, YU QM, DU YA, YANG LT, DONG RZ, et al. Knockdown of long non-coding RNA HOTAIR suppresses tumor invasion and reverses epithelial-mesenchymal transition in gastric cancer. International journal of biological sciences 2013; 9: 587-597. http://dx.doi.org/10.7150/ijbs.6339

[74] NIINUMA T, SUZUKI H, NOJIMA M, NOSHO K, YAMAMOTO H, et al. Upregulation of miR-196a and HOTAIR drive malignant character in gastrointestinal stromal tumors. Cancer Res 2012; 72: 1126-1136. http://dx.doi. org/10.1158/0008-5472.CAN-11-1803

[75] STRATFORD JK, BENTREM DJ, ANDERSON JM, FAN C, VOLMAR KA, et al. A six-gene signature predicts survival of patients with localized pancreatic ductal adenocarcinoma.
PLoS Med 2010; 7:e1000307. http://dx.doi.org/10.1371/journal.pmed.1000307

[76] BAEK SJ, KIM JS, MOORE SM, LEE SH, MARTINEZ J, ELING TE. Cyclooxygenase inhibitors induce the expression of the tumor suppressor gene EGR-1, which results in the up-regulation of NAG-1, an antitumorigenic protein. Mol Pharmacol 2005; 67: 356-364. http://dx.doi.org/10.1124/ mol.104.005108

[77] BAEK SJ, HOROWITZ JM, ELING TE. Molecular cloning and characterization of human nonsteroidalanti-inflammatory drug-activated gene promoter. Basal transcription is mediated by Sp1 and Sp3. J Biol Chem 2001; $276: 33384-33392$. http://dx.doi.org/10.1074/jbc.M101814200

[78] LIU XH, LIU ZL, SUN M, LIU J, WANG ZX, et al. The long non-coding RNA HOTAIR indicates a poor prognosis and promotes metastasis in non-small cell lung cancer. BMC cancer 2013; 13: 464. http://dx.doi.org/10.1186/1471-2407$\underline{13-464}$

[79] NAKAGAWA T, ENDO H, YOKOYAMA M, ABE J, TAMAI $\mathrm{K}$, et al. Large noncoding RNA HOTAIR enhances aggressive biological behavior and is associated with short disease-free survival in human non-small cell lung cancer. Biochemical and biophysical research communications. 2013; 436: 319-324. http://dx.doi.org/10.1016/j.bbrc.2013.05.101

[80] LIU XH, LU KH, WANG KM, SUN M, ZHANG EB, et al. MicroRNA-196a promotes non-small cell lung cancer cell proliferation and invasion through targeting HOXA5. BMC cancer 2012; 12: 348. http://dx.doi.org/10.1186/1471-2407$\underline{12-348}$

[81] ZHUANG Y, WANG X, NGUYEN HT, ZHUO Y, CUI X, et al. Induction of long intergenic non-coding RNA HOTAIR in lung cancer cells by type I collagen. Journal of hematology \& oncology 2013; 6: 35. http://dx.doi.org/10.1186/1756-8722$\underline{6-35}$

[82] LI D, FENG J, WU T, WANG Y, SUN Y, et al. Long Intergenic Noncoding RNA HOTAIR Is Overexpressed and Regulates PTEN Methylation in Laryngeal Squamofus Cell Carcinoma. Am J Pathol. 2013; 182: 64-70. http://dx.doi.org/10.1016/ j.ajpath.2012.08.042

[83] NIE Y, LIU X, QU S, SONG E, ZOU H, et al. Long noncoding RNA HOTAIR is an independent prognostic marker for nasopharyngeal carcinoma progression and survival. Cancer Sci 2013; 104: 458-464. http://dx.doi.org/10.1111/cas.12092

[84] LV XB, LIAN GY, WANG HR, SONG E, YAO H, et al. Long Noncoding RNA HOTAIR Is a Prognostic Marker for Esophageal Squamous Cell Carcinoma Progression and Survival. PloS one 2013; 8: e63516. http://dx.doi.org/10.1371/journal. pone.0063516

[85] HE X, BAO W, LI X, CHEN Z, CHE Q, et al. The long non-coding RNA HOTAIR is upregulated in endometrial carcinoma and correlates with poor prognosis. International journal of molecular medicine; 2014; 33: 325-332.

[86] CHEN FJ, SUN M, LI SQ, WU QQ, JI L, et al. Upregulation of the long non-coding RNA HOTAIR promotes esophageal squamous cell carcinoma metastasis and poor prognosis. Molecular Carcinogenesis 2012; 52: 908-915. http://dx.doi. org/10.1002/mc.21944 
[87] LI X, WU Z, MEI Q, LI X, GUO M, et al. Long non-coding RNA HOTAIR, a driver of malignancy, predicts negative prognosis and exhibits oncogenic activity in oesophageal squamous cell carcinoma. British journal of cancer 2013; 109: 2266-2278. http://dx.doi.org/10.1038/bjc.2013.548

[88] ZHANG J X, HAN L, BAO Z S,WANG YY, CHEN LY, et al. HOTAIR, a cell cycle-associated long noncoding RNA and a strong predictor of survival, is preferentially expressed in classical and mesenchymal glioma. Neuro-oncology; 2013; 15: 1595-1603. http://dx.doi.org/10.1093/neuonc/not131

[89] TANG L, ZHANG W, SU B,YU B. Long Noncoding RNA HOTAIR Is Associated with Motility, Invasion, and Metastatic Potential of Metastatic Melanoma. BioMed Research International; 2013: 251098. 